\title{
Kerklike verkondiging in dialekties-teologiese perspektief ('n Teug uit die ou teologiese velsakke)
}

F J van Zyl

Professor emeritus: Departement Godsdiens- en Sendingwetenskap Fakulteit Teologie (Afd A)

Universiteit van Pretoria

\begin{abstract}
The message of the church in view of dialectical theology (A sip of theology from the old wine-skins)

This article attempts to ascertain the essence of the message preached by churches whose dogma is influenced by dialectical theology, especially that of Karl Barth. The basic point of departure is that although the theology to which churches subscribe is not actually preached, the content and quality of sermons cannot escape its influence. As dialectical theology is generally regarded and understood as an extension of Reformation theology, it is imperative to integrate both the basic truths of Reformation theology and the innovative trends of dialectic thinking as far as the preaching of the gospel is concerned. In view of the enormous scope of Barthian theology, the author was compelled to limit his article to the essence of the church's message, namely the gospel of reconciliation, according to many scholars the heart of Barth's theology.
\end{abstract}

\section{INLEIDING}

\subsection{Teologie en kerklike verkondiging}

Met die oog op die tema van hierdie artikel en ter opskerping van die geheue is dit miskien goed om heel aan die begin te luister na wat Barth, grondlêer van die dialektiese teologie, onder teologie verstaan. Die stilswyende veronderstelling is dat wat hy oor dogmatiek sê, vir al die teologiese vakke geld. Miskien het hy nergens saakliker, duideliker en verstaanbaarder oor hierdie saak gepraat as in sy Dogmatiek in hooftrekke (Dogmatik im Grundrisz) nie (Barth 1947:9-15). Daar verneem ons dat 'dogmatiek die wetenskap is waarin die kerk, in ooreenstemming met die kerk se kennis op daardie comblik, sigself krities rekenskap gee van die inhoud van die kerk se prediking, dit wil 
sê volgens die maatstaf van die Heilige Skrif en die onderrig van die kerk se belydenis'. Enkele sake uit hierdie inleidende hoofsin, moet uitgelig word:

* Wetenskap is 'n menslike poging om 'n bepaalde lewensgebied te bestudeer, te verstaan, uit te beeld en iets leersaams daaroor te sê. Geen menslike handeling en onderneming, ook wetenskap, kan meer as slegs 'n poging wees nie. Daardeur word die voorlopigheid en begrensdheid van alle wetenskap gekonstateer.

* Die Christelike kerk is subjek van die teologie. Net hulle wat met die objek van ondersoek bekend is, daarby teenwoordig is en vertroud is met daardie lewensgebied, kan subjek van 'n wetenskap wees. Die kerk is die gemeenskap aan wie die voorwerp en die handeling waarop die teologie gerig is, naamlik die verkondiging van die evangelie, opgedra is. Waar teologie beofen word, studerend of lerend, daar bevind 'n mens jou in die ruimte van die kerk.

* In die teologie gee die kerk vir sigself rekenskap oor die inhoud van die verkondiging, ooreenkomstig die stand van die kerk se kennis op daardie oomblik. Almal in die kerk het ongelukkig nie dieselfde opvatting oor teologie nie. Omdat ons maar net aardse mense is en die kerk net op die aarde en in die tyd in menslike en aardse verhoudings aan ons gegee is, bestaan daar nie so iets soos 'n absolute teologie nie. So loop die kerk 'n pad in die wêreld deur die loop van die geskiedenis, in die besit en die bediening van die uitnemende gawes aan die kerk gegee is, in krag en swakheid, in trou en ontrou, in gehoorsaamheid en ongehoorsaamheid, met begrip en gebrek aan insig van wat aan die kerk gesê is. Daarom moet die kerk maar beskeie wees oor alles wat in die kerk verrig word, ook op die gebied van die teologie. Nooit sal dit 'n volmaakte saak wees nie. Wat navorsing en formulering betref, bly dit 'n relatiewe saak, gegrond op 'n dinkvermoē wat altyd die moontlikheid van vergissing en dwaling bevat. Ook by die beste teologiese arbeid kan alleen verlang word na wat nog beter sal wees. Intussen kan ons rustig voortwerk en ons kennis gebruik soos wat dit op hierdie oomblik aan ons geskenk is.

* As wetenskap gee die teologie rekenskap betreffende die inhoud van die kerklike verkondiging. As die taak van die kerk nie in die verkondiging van die evangelie bestaan het nie, sou daar geen teologie gewees het nie. Dit is ' $n$ opdrag nie net aan doserende teoloē en predikante nie, maar aan die hele kerk. Die kerk behoort die plek in die wêreld te wees waar 'n woord weerklink. Die dringende vraag is wat ons almal as Christene in die wêreld te sê het. 
* As kritiese wetenskap meet die teologie die kerklike verkondiging met tweeërlei maatstaf:

i) die Heilige Skrif as dokument van die verskyning van die Woord van God in die persoon van Jesus Christus. Dit gaan in die verkondiging nie om 'n ge-tuienis van die predikant se hart of denke nie, maar om die getuienis van apostels en profete as getuienis van wat God self getuig het;

ii) die kerk se belydenis. Dit is nie so dat Skrif en belydenis met dieselfde respek en liefde behandel moet word nie. Dit verander egter niks daaraan dat die getuienis van die vadere in die kerk gehoor en gerespekteer word nie. God se Woord word weliswaar by hulle nie gehoor soos by apostels en profete nie, maar dit het tog in die kerk 'n groot en gewigtige betekenis in gehoorsaamheid aan die vyfde gebod. Bindende gesag soos die Skrif het hulle getuienis nie, maar wel nie-verpligtende, relatiewe gesag waarmee ernstig rekening behoort gehou te word.

* As kritiese kerklike wetenskap funksioneer die teologie, deur rekenskap te gee van die inhoud van die kerk se verkondiging asook van die verhouding tussen daadwerklike verkondiging en wat behoort te geld as verkondiging, as getroue weergawe van wat aan die kerk gesê is. Wat in die kerk behoort te geld as getroue weergawe van die Woord van God, word dogma genoem. Teologie kan dus 'n kontrolerende en korrektiewe funksie vervul om die prediking 'n beter gestalte te gee. Uiteindelik kan God alleen deur God se Gees die nodige korrektief en verdieping bewerk, egter nie sonder menslike teologiese bemoeiing nie.

\subsection{Die teologie van die Nederduitsch Hervormde Kerk}

In dialektiese trant moet op die implisiet-positiewe uitspraak van hierdie paragraafopskrif, die Nee volg: die Nederduitsch Hervormde Kerk het nie 'n eie teologie nie. Hoogstens kan 'n mens sê dat hierdie kerk in die beoefening van teologie, voorkeur gee aan 'n bepaalde teologiese denkrigting, wyer as eie kerkgrense. Hierdie denkrigting word by die naam genoem toe die eerste teologiese tydskrif van die kerk se teologiese fakulteit aan die Universiteit van Pretoria verskyn het: Hervormde Teologiese Studies. Die aanvanklike uitgawes van hierdie tydskrif het die volgende byskrif by die naam gehad: 'vir die bevordering van die Bybels-Reformatoriese teologie in Suid-Afrika'. Meermale word dit egter nog deur die huidige redakteur van die HTS en ander instansies van die kerk bevestig dat ons in die Bybels-Reformatoriese tradisie teologie wil beoefen. Om die 'Bybels-Reformatories' nog sterker te beklemtoon, is ook nog 'Dia- 
lekties' daarby gevoeg. Bybels-Reformatories-Dialektiese teologie: dit klink inderdaad indrukwekkend. Die vraag is of ons werklik getrou is aan hierdie uitgebreide doelstelling van teologiebeoefening. Dis nodig om weereens duidelikheid te kry oor wat 'Bybels-Reformatories' en 'dialekties' beteken in die beoefening van ons teologie.

Dat die twee saam genoem word, is ' $n$ aanduiding dat hulle in noue verband met mekaar staan. Dialektiese teologie kan verstaan word as verlengstuk van die Reformatoriese, nie in die sin van repristinasie nie, maar as vernuwende voortgang. Albei wil teologie van die Woord wees, beskou die Bybel as enigste outentieke getuienis van die selfbekendmaking van God in die mensgeworde Woord, deur die menslike getuienis van apostels en profete. Die vraag kan gestel word of dit nie voldoende is om van Bybelse teologie te praat nie. Ongelukkig verstaan almal nie die Bybel eenders nie. Elke ketter het sy letter. As die voorneme is om Bybels-Reformatories teologie te beoefen, beteken dit slegs dat geteologiseer word met die Bybel, soos deur die Reformatore verstaan, as grondslag, inhoud en norm daarvan. Enkele hooftrekke van Reformatoriese Skrifbeskouing kan soos volg aangestip word:

* Teenoor die Rooms-Katolieke siening waardeur die kerklike tradisie as 'n historieskontinue grootheid naas die eenmalige openbaring in Jesus Christus, waarvan slegs die Skrif getuig, gestel is met gelyke reg, poneer die Reformatore die sola scriptura.

* Die woord wat God in Jesus Christus eens en vir altyd gespreek het, kan net Hy alleen op enige ander tydstip in die geskiedenis weer spreek in die hart van 'n mens deur die Heilige Gees.

* Die Bybel is nie direk gelyk aan die Woord van God nie, maar moet dit altyd weer word as die paradoksale eenheid van Skrifwoord (mense-woord) en Godswoord plaasvind wanneer die sprekende stem van God in en deur die Skrifwoord verneem word (vir voorgaande stellings, vgl Brunner 1931:9). Die dialekties-teologiese beskouing oor die Skrif, in hierdie artikel dié van Barth, kom in hooftrekke ooreen met dié van Brunner. Wat hierdie saak betref, sou 'n mens kon sê dat die nuwe wat Barth na vore gebring het, die klem is op Jesus Christus as die mensgeworde Woord van God en as sentrum van die hele Skrif. Die Christosentriese Skrifbeskouing tipeer ook sy teologie in totaliteit.

Hoewel daar tussen twee van die vernaamste aanvanklike hoofmanne van die dialektiese teologie, Barth en Brunner, baie teologiese raakpunte bestaan, moet die oê nie gesluit word vir diepgaande verskille wat uitgangspunt betref nie. Dit blyk al dadelik as Brunner, nie soos Barth, teologie sien as kritiese ondersoek betref- 
fende kerklike verkondiging nie, maar as die wetenskaplik-abstrakte vorm van die Christelike geloof, as kennis en erkenning van God se selfbekendmaking in Jesus Christus. 'n Mens sou kon sê dat by Barth die objektiewe waarheid van die Woord primêre belangstelling geniet, terwyl Brunner meer geïnteresseerd is in die mens wat daardie waarheid glo. Naas die saak waar dit om gaan in die verkondiging, reken Brunner dat die teologie ook nog 'n ander taak het, gerig op die mens aan wie die evangelie verkondig word. Die teologie wat hy beoefen, noem hy Eristiek omdat dit meer let op die moeilikhede en teenstand van die kant van die mens aan wie verkondig word. Hierdie teologie wil ad hominem spreek.

Dit het gelei tot die probleem van die aanknopingspunt in die mens vir die boodskap van God. Brunner erken so 'n aanknopingspunt, hoewel nie as iets positiefs nie. Hy sien dit meer as iets negatiefs in die mens en bepaal dit nader as bewussyn van die Frage, waar dit die gestalte van lewensnood aangeneem het (Brunner 1931:8). Brunner se Eristiek wil die mens help om sy vraag na God reg te verstaan deur daarop te wys dat hy 'Mensch im Widerspruch' is, dus sondige mens in verset teen God. Barth se antwoord op Brunner se beskouing oor die hele kwessie van die aanknopingspunt was 'n besliste 'Nein', en daarmee die tragiese uitmekaar gaan van twee eminente teoloë, 'n voldonge feit.

Op die oog af lyk dit of Brunner se 'andere Aufgabe der Theologie' 'n swaai na die fides qua toe kan wees en dat die post-moderne, meer diesseitig en mensgerigte teologie, by hom dalk sou kon aansluit. Omdat geloof tog immers 'n menslike daad is, sal daar altyd plek moet wees vir die fides qua teenoor die fides quae, solank maar net nie vergeet word dat die quae die qua tevoorskyn roep nie. Brunner was egter te oortuigde Bybels-Reformatoriese teoloog dat hy die objektiewe heil extra nos deur enige subjektivisme sou laat absorbeer. Miskien sou hy hier-en-daar wel 'n kopknik van instemming kon ontlok het, byvoorbeeld by Bultmann.

'n Goeie bondgenoot het die nuwe teologiese rigting ongetwyfeld in die Korrelasieteoloog-filosoof, Paul Tillich. Volgens hom praat die kerk oor die kop van die moderne mens, as daar nie antwoord gegee word op die vrae wat in hierdie bepaalde tyd leef in die harte van mense nie. Sy teologiese sisteem word vanuit 'n apologetiese hoek aangebied en in voortdurende korrelasie met die filosofie. Dit is die filosoof se taak om die vrae te identifiseer en te formuleer, wat daar in 'n bepaalde tyd by mense leef, en die teoloog se taak om antwoorde daarop te gee. In die voorwoord tot sy Systematic Theology (vol 1) beskryf Tillich (1951) die oogmerk van sy teologie as 'a help in answering questions'. Tillich is meer begaan oor die situasie waarin die evangelieboodskap moet tuis kom. Dit is algemene kennis dat die teologiese wending sedert die 
sestigerjare, bekend as die vernuwings-, of neo-moderne-, of post-moderne teologie, ook in ons eie teologiebeoefening neerslag gevind en woordvoerders gekry het.

Die volgende uitsprake uit eie geledere klink Tillichiaans (Van Aarde 1995:15-16): 'Die term 'paradigma' (era) ... wys na die totaliteit van denke, persepsies en waardes binne die wetenskaplike gemeenskap wat lei tot 'n spesifieke visie op die werklikheid. Hierdie visie vorm die grondslag van 'n voorstellingswêreld wat mense in staat stel om model-probleme te identifiseer en model-oplossings daarvoor aan die hand te doen'. 'n Model-probleem is so een wat nie net ontstaan by een of ' $n$ paar navorsers nie, maar by die 'geleerde gemeenskap' en by implikasie is dit dan hierdie uitgelese gemeenskap wat die model-oplossings aan die hand doen. Eintlik het Tillich se filosoof-wees wat vrae identifiseer en sy teoloog-wees wat hulle moet beantwoord, net meer lyf gekry. Omdat teologie as wetenskap beoefen word binne ' $n$ wêrelduniversum van wetenskappe is dit so: 'Vrae wat op die gebied van die fisika en die filosofie gestel word, beinnloed wesenlik die teologiese vraagstelling ... soos die teoriee oor die ontstaan van die wêreld, die aarde en sonnestelsels, verander, pas die filosofie hierby aan en kan die teologie nie anders as om op grond van die heersende filosofie weer nuut te spreek nie, sonder om aan die filosofie of fisika "verkneg" te word' (Van Aarde 1995a:15-16).

Dat die post-moderne teologie wel deeglik figureer, word verder duidelik uit die volgende: Op weg na die derde millenium en met die oog op die kleiner wordende wêreld wat van die wêreld as gevolg van die tegnologie 'n 'global village' gemaak het, behoort kerk en teologie, met handhawing van beginsels van die Reformatoriese en Dialektiese teologie, behalwe aandag aan die ekumeniese gesprek, 'naas die kognitiewe meer aandag te gee aan die emotiewe en die pragmatiese' (Van Aarde 1995b:58). Na aanleiding van al die voorafgaande, enkele opmerkings wat nie bedoel word om swaarde te kruis nie, maar die noodsaaklke teologiese diskussie te stimuleer:

* Dit bly nog altyd nie duidelik wat die aard van die probleme is wat die wetenskaplike gemeenskap identifiseer en watter oplossings daarvoor aan die hand gedoen word nie. Daar word wel gesê dat dit nie bloot maatskaplike lewensmoeilikhede is nie, hoewel tog gepraat word van 'nood op die grondvlak van die samelewing' (Van Aarde 1995:51). Dat die wetenskaplike gemeenskap sulke nood kan identifiseer, is moontlik. 'n Mens hoef seker ook nie 'n wetenskaplike te wees om maatskaplike nood van 'n gemeenskap raak te sien nie. Die eintlike nood waarmee die teologie gemoeid is, is groter as 'n probleem en so gekamoefleer dat geen mens, wetenskaplike of gewone mens, dit uit homself of haarself kan ken nie. Dat veranderende teorieë betreffende die ontstaan van aarde en wêreld, nuwe sonnestelsels en so meer, die kerk noop om nuut te spreek, lê eintlik voor die hand. 
solank die 'nuut' nie 'anders' beteken nie, maar die ou, ewige evangelie op nuut. Die wesenlike waar dit vir die kerk om gaan te midde van die vrae van die kant van die fisika en die filosofie, is die antwoord wat die Woord lank tevore reeds gegee het in die bevestigende vraag: 'Wat is die mens dan dat $\mathrm{U}$ aan hom dink, die mensekind dat U na hom omsien?' (Ps 8:5). Die aap word egter uit die mou van die nuwe teologie gelaat as gemeld word dat vrae op die gebied van fisika en filosofie 'die eksegese van die Bybel en die interpretasie van die geloofsgemeenskap se klassieke en eietydse belydenisse' insluit. By implikasie word hier waarskynlik gedink aan die eksistensiaal-hermeneutiese en ontmitologiseringsprobleem wat deur Bultmann aan die orde gestel is en aktueel geword het rondom die belydenis van die maagdelike geboorte en veral die opstanding van Jesus Christus.

* Naas die kognitiewe in die Reformatoriese en Dialektiese teologie, word daar meer aandag vir die emotiewe gevra. Barth het per geleentheid van 'n radio-onderhoud, gepraat van twee pole in die geloofsverhouding, God en mens. Jesus Christus is die enigste brug tussen hierdie twee pole. Wat die goddelike pool betref, word van die mens verheerliking gevra, terwyl kennis van die diepe sorge van die mens as ander pool gevra word (Barth 1961:81). Wie enigsins kennis dra van Barth se dogmatiek in totaliteit, sal weet watter belangrike plek die mens beklee in skepping, verkiesing, verbond, versoening, regverdiging, heiliging en verlossing. Medemenslikheid en menswees is vir Barth onafskeidelik met mekaar verbonde. In die dialektiese teologie het die emotiewe nooit ontbreek nie, hoewel Barth (1960:105) self erken dat die menslike pool miskien nie genoegsaam beklemtoon is nie.

* Miskien verdien die aandag wat van kerk en teologie gevra word vir die pragmatiese op pad na die derde millenium, ook 'n opmerking of twee. Dit is 'n woord wat sterk herinner aan die Amerikaanse mentaliteit wat praktyk gerig is en in aansluiting by die werklikeid eerstens vra of 'n saak, 'n instelling, werk. Groot klem word gelê op menslike aktiwiteit en soms word selfs gepraat van 'church business'. Dit is alles lynreg in teenstelling met die visie van die dialektiese teologie. Dit is interessant om te hoor wat Noordmans (1930) te sê het oor 'De Zwitserse Theologie', na aanleiding van Barth se kommentaar op die Brief aan die. Romeine. 'Op allerlei wijse hebben wij de nadruk hooren leggen op den menschelijken factor in den bijbel; de menschheid van Jezus; het humaan karakter van het godsdienstig leven; het etisch gehalte van de waarheid; het praktische in het christendom ... daarover hebben wij veel gehoord. Sommigen zeggen: genoeg. Anderen meenen: 
meer dan genoeg. Tot de laatsten behooren ook ... Barth, Brunner, Turneysen ...' Hy beskou Barth as die corspronklikste (Noordmans 1930:37). Die kerk sal wat die pragmatiese betref, op die hoede moet wees om nie te verval tot Israelitiese tempeldiens nie, en bowe al sal die kerk moet toesien dat allerlei 'side shows' nie belangriker word as die regte verkondiging van die evangelie nie.

\section{DIALEKTIESE TEOLOGIE (VERAL DIE TEOLOGIE VAN BARTH)}

\subsection{Formele tipering}

Die teologie van Barth is al onder verskillende benamings getipeer, soos teologie van die Woord, openbaringsteologie, teosentriese en krisisteologie. Van die begin af het Barth hom verset teen die gedagte van 'n teologiese, logies sistematiese sisteem en van 'n enersdenkende skool. Hy wou slegs enkele kritiese kanttekeninge maak by die teologie van sy dag, nie binne die eng mure van 'n skool nie, maar in die wye ruimte van die kerk. Die kanttekeninge het uitgegroei tot etlike lywige boekdele, wat onder die algemene benaming van Dialektiese Teologie bekend staan en ook werk van ander teoloë soos onder andere Brunner en Gogarten dek. Barth het self nooit 'n direkte aanduiding gegee van wat hy onder dialektiese teologie verstaan nie. Die naaste aan 'n eie tipering het hy gekom deur te verwys na die invloed van Kierkegaard se uitspraak oor die absolute kwalitatiewe wesensverskil tussen ewigheid en tyd, God en mens, op sy eie denke. Dit impliseer onmiddellik 'n spanning, 'n bepaalde teenspraak betreffende die Jenseitigkeit en soewereiniteit van God en God se selfopenbaring aan die een kant en die Diesseitigkeit en relatiwiteit van alle menslike handeling aan die ander kant. Dit problematiseer die moontlikheid om God se Woord in mensewoorde te omvat, en lei tot die volgende bekende dialektiese uitspraak: finitum non capax infiniti. Soos verderaan gesien sal word, het Van Niftrik aan hierdie saak die nodige aandag gegee.

In teenstelling met Barth het Brunner hom eksplisiet uitgespreek oor die betekenis van 'dialekties' in die benaming van hierdie teologie. Uitgaande ook van die kwalitatiewe wesensverskil tussen God en mens en van die onbegryplike en onverklaarbare, maar slegs konstateerbare feit van die sonde, waardeur God se goedgeskape maaksel verval tot rebel teenoor sy Skepper, tipeer Brunner die bestaan van die mens as 'Mensch im Widerspruch', mens in sondige verset en teenspraak teen God. Omdat die Woord van God die mens in sy sondige verset en teenspraak teen Hom ontmoet, is dialekties vir hom die enigste passende benaming vir hierdie teologie wat die beste weergegee kan word met: afbeelding van sondige verset. Daarom is dit self paradoksale woord in teenspraak soos: Godmens, vryheid as knegskap van God, die kruis as openbaring van die heerlikheid van God (Brunner 1929:266, anm 5; Haitjema 1948:8). 
Van Niftrik (1948:52-59) gaan in sy tipering van Dialektiese Teologie van twee basiese vooronderstellings uit: 1) die kwalitatiewe verskil tussen God en mens, 2) die Christologie, die menswording van die ewige Woord as sentrale feit van Bybelse verkondiging. Wat 1) betref, is dit uitgesluit dat ons direkte kennis van God kan hê. Menslike woord en begrip skiet te kort om die werklikheid van God uit te spreek. Dit kan nie met een woord gedoen word nie en moet dus met 'n tweede opgevolg word. As iets beweer word in verband met God, moet ' $n$ mens jouself dadelik in die rede val en jou Ja met ' $n$ Nee deurkruis en omgekeerd. Om met twee woorde te spreek, beteken om dialekties te spreek. Aansluitend hierby word 2) ook verstaanbaar. Die sentrale feit van die Bybelse boodskap is dat die Woord mens geword het, dat Hy 'Immanuel' genoem word en God in Hom däs met ons is. In teologie en verkondiging kan die kerk dus nooit met 'n abstrakte God te doen hê nie wat alleen in hemelse heerlikheid God is, en kan oor die God van die Bybel nie anders as dialekties gepraat word nie, naamlik as Vader van Jesus Christus wat in een persoon tegelyk ware God en ware mens is. Die Godheid van Jesus Christus is alleen in die feit gelee dat Hy mens is, want alleen God kan God se eie grens oorskry deur mens te word en nog God te bly (Barth 1953:86-87). Wie God sê, moet ook mens sê. Daarbenewens beteken kerklike verkondiging (volgens die apostel Paulus). Christus-verkondiging, en dit weer verkondiging van die lewende Christus wat gekruisig is. Die menswording van God beteken tegelyk in kruis en opstanding van Jesus Christus die vernedering van God tot die mens in die diepste verlorenheid en die verhoging van die mens tot hoogste heerlikheid by God. Die Christus-gebeure in kruis en opstanding word as dwang op kerklike spreke in die teologie gelê volgens die dialektiese metode. Kruis en opstanding kan nooit los van mekaar verkondig word nie, want die Gekruisigde is die Opgestane en omgekeerd. Albei moet gesê word, en dit kan alleen geskied in 'n dialektiese heen-en-weer wat beweeg om die onaanskoulike middelpunt: God wat mens geword het.

Ten slotte moet gemeld word dat ook die dialektiese wyse van spreke oor God, nie by magte is om hierdie inhoud te omvat nie. Histories is dit egter ook in ooreenstemming met die spreke van Paulus en die Reformatore. Van al die menslike metodes van spreke, is dit die metode wat die beste reg laat geskied aan die geheimenis, vryheid en soewereiniteit van God, omdat dit rekening hou met die kwalitatiewe verskil tussen ewigheid en tyd en met die menswording van die ewige Woord.

\subsection{Inhoudelike bepaling}

As 'n mens in gedagte hou dat net Die Kirchliche Dogmatik (KD) uit 12 boekdele bestaan, met ongeveer 9000 bladsye, is dit begryplik dat 'n geslag teoloè, wat nie saam met hierdie teologie kon groei nie, afgeskrik kan word deur die uiterlike massiwiteit 
daarvan. Gelukkig is daar enkeles wat reeds hierdie ontsagwekkende teologiese bergreeks verken het en vir ons wat later gekom het, die wandelpaaie uitgestippel het sodat ons ook kennis kan maak met die styl kranse en diep klowe daarvan en veral die fris en suiwer berglug en wonderskone vergesigte die verlede en toekoms in, kan beleef en geniet. Die koers verder sal dan ook hoofsaaklik langs die wandelpad van Otto Weber gaan, met erkenning ook van die hulp wat tot op hierdie punt reeds deur G $\mathbf{C}$ van Niftrik gelewer is. Oor meer as enkele hoofgedagtes kan dit helaas nie gaan nie.

Terwyl die teologie van Barth reeds met ' $n$ bergreeks vergelyk is, kan in die terminologie van die post-moderne teologie, met hierdie metafoor gerus voortgegaan word, en gepraat word van drie pieke in hierdie bergreeks. Die middelste van hierdie drie is ook die hoogste vanwaar 'n mens terug- en vooruitskouend ook die ander twee kan oorskou. Jüngel (in Van Niftrik 1969:311) noem hierdie hoogste piek die meesterwerk van Barth, en Weber beskou dit as sentrum van die totale $K \boldsymbol{D}$ met die voorafgaande skeppingsleer en die daarop volgende eskatologie, as omlysting daarvan (Weber 1963:191). Daarom beperk ons onsself hoofsaaklik tot hierdie middelpunt by die bepaling van die saaklike inhoud van hierdie teologie.

Anders as Jüngel praat Barth nie van Christologie nie, maar van versoeningsleer en wat laasgenoemde betref, wyk hy ook aansienlik af van die tradisionele volgorde van gedagtes. Gewoonlik volg die leer oor die sonde direk na die skeppingsleer, dan volg die beskouing oor die persoon van die Verlosser en daarby aansluitend die versoeningswerk. Barth breek heeltemal met hierdie volgorde en laat volg sy sondeleer eers na die Christologie, terwyl persoon en werk van die Verlosser in die Christologie as 'n eenheid behandel word. Ingrypender as al die nuwe in die teologie waarop die aandag reeds gevestig is en die wat nog gaan volg, is miskien sy behandeling van die Christologie en die soteriologie as 'n eenheid. Konkreet kan die twee volgens Barth (1953135) nie onderskei word nie en is heeltemal in coreenstemming met Nuwe-Testamentiese getuienis. In elk geval beteken die byeenbring van Christolgie en versoeningsleer geensins dat die basiese beslissings van die ou kerk, soos byvoorbeeld vervat in die formulering van Chalcedon oor Jesus Christus as ware God en ware mens, in die slag gebly het nie. Wat wel in die slag bly, is wat die ou dogmatiek oor die persoon van Jesus Christus te sê het. Hieroor merk Van Niftrik op dat die persoon van Christus 'n geheimenis is. Die kerk bewaar in die beslissings (Chalcedon) die geheimenis as geheimenis. 'Het dogma zegt nadrukkelijker hoe het niet dan hoe het wel is' (Van Niftrik 1940:88). Hy voeg by dat die dogma kettery wil keer. 'Het gaat om het rechte verkondiging van Christus'. Hiermee kan volmondig saamgestem word en daarom is Barth se voorstel myns insiens sinvol: dat die werk van Christus ten volle opgeneem word in die leer oor Christus se persoon en omgekeerd. Die twee nature en twee state 
van Christus behandel hy dan ook as een. In die eenheid van persoon en werk van Jesus word die vernedering dus as die Goddelike gesien, en die verhoging as die werk wat die mens te beurt val. Dit is in kort die kern van Barth se versoeningsleer of Christologie, alternatiewelik, die evangelie in 'n neutedop.

Barth (1953:1) begin sy versoeningsleer met die stelling dat 'objek, oorsprong en inhoud van die boodskap wat deur die Christelike kerk verneem is en verkondig word, in sy sentrum die vrye daad van God se trou is, waardeur God die verlore saak van die mens, wat God as die mens se Skepper verloën het en sodoende homself en haarself as God se maaksel (skepsel) in die verderf gestort het, in Jesus Christus God se eie maak en tot volvoering bring en daardeur. God se eie eer in die wêreld handhaaf en bekend maak.' As Barth dus in teenstelling met die gebruiklike gedagtegang, die sondeleer nie voor nie, maar na die versoeningsdaad stel, is dit duidelik dat God se versoeningsdaad in Jesus Christus nie gegrond is in die sondefeit nie. As daar in voornoemde stelling egter gepraat word van die verlore saak van die mens, die verloëning van die mens se Skepper en van die mens se eie verderf, blyk dit dat die sonde as daad en feit nie uit die oog verloor word nie. In die versoeningsleer neem dit egter nie die eerste plek in nie, maar die tweede. Veeleer kom die eerste plek die verbond van God toe, want versoening beteken vervulling van die verbond tussen God en mens (Barth 1953:22vv). Hierdie vervulde verbond, dit wil sê die versoening, is die sentrum van die Christelike boodskap, dus ook van die dogmatiese teologie wat op die verkondiging gerig is. Verkeerde of gebrekkige kennis hier, beteken verdraaiing of mislukking in die geheel: verskraling of verduistering van die boodskap, van die belydenis en ook van die teologie (Barth 1953:1).

Verbond beteken God-met-ons en Barth beskou dit as 'n algemene prospektus oor die hele kennisgebied van die versoening. 'God-met-ons' het verskillende betekenisse (vgl Barth 1953:4-15; Weber 1963:191vv): Dit is daad van God wat plaasvind, dié besondere daad van saamwees van God en mens waardeur die gemeenskaplike geskiedenis van Skepper en skepsel, heilsgeskiedenis vir die mens word; hierdie heil is geen toegif by die skepping van die mens nie, maar ' $n$ toesegging van alle ewigheid af uit die vryheid van God se liefde; hierdie liefde is egter heilloos, jammerlik deur die mens verspeel deurdat die mens die rug daarop gedraai het en self die heil wou verwerklik; Godmet-ons beteken God met hierdie sondige mens wat die rug op God en God se heil gedraai het, beteken die daad van God wat alles behalwe die blinde paradoks van 'n willekeurige goddelike genadedaad is, maar 'n daad waartoe God van ewigheid af God self verbind het tot voltrekking daarvan; Dit is die vermoë van God wat tot God se wese behoort, om mens te word en tog anders mens te wees as ons almal, deurdat God doen wat ons almal nalaat en nalaat wat ons almal doen; dié mens te word in Wie God self 
vir ons intree, vir ons ly en handel, wat as ons plaasvervanger, namens ons en tot ons beswil, die afgrond tussen God en ons verwyder, wat nie net bevestiging en waarborg van ons heil is nie, maar dit Self is omdat God God is. Vandaar word dit duidelik dat 'God-met-ons' ook 'ons-met-God' insluit. Met die oog daarop dat ons sulke mense is in wie se plek iemand anders getree het, wat vir hulle lewe, ly en handel, vir hulle goed maak wat hulle verbrou het en self hulle heil is, ontstaan die vraag waar ons dan nou eintlik staan. In hoe verre is die verhaal van God se dade in hierdie hoogtepunt en middelpunt ook ons eie verhaal? Het ons nie dalk nou net blote objekte geword sonder 'n eie geskiedenis, in 'n posisie van onverantwoordelikheid geplaas waar ons net nog toeskouers is nie? Het ons bestaan nie leweloos en daadloos en gevolglik betekenisloos geword nie?

Hierop antwoord Barth (1963:14) dat God, deur God se daad vir ons en in ons plek, ons onmiddellik oproep en opwek tot ons eintlike bestaan en daad en dat God God self in daardie een Mens tot vredestigter tussen God en ons en as skenker en geskenk van ons heil maak. Juis die verwerkliking van God se heilswil deur God self open vir ons die enigste en ware moontlikheid van ons eie bestaan. Dit beteken nie opheffing van ons menslikheid nie, maar die fundering daarvan, nie passiewe toeskouersbestaan nie, maar eintlike en hoogste aktivering, naamlik tot lofprysing van God se genade, dit is egte menslike bestaan, dit beteken ons-met-God. Dit weer is Christelike geloof, Christelike liefde en Christelike hoop as inhoud van ons lofprysing. Omdat hierdie lofprysing uit die diepte van ons verlorenheid kom, kan dit die waarheid en krag nie in sigself hê nie, maar net in God en dus in daardie cen Mens in Wie God vir ons is.

Vervolgens kom Barth by die belangrike vraag, hoe die kerk weet van die boodskap wat die kerk ontvang het en moet oordra, dit wil sê die kwessie van kennis en kommunikasie van die God-met-ons. Die kerk se antwoord is daarom belangrik, omdat hierin duidelik afgegrens word teen Bultmann met betrekking tot die subjek-objek denkskema. Dit is 'n denkskema hierdie wat teruggevoer moet word na die piëtistiesromantiese reaksie teen die na-Reformatoriese fundamentalisme van die ortodoksie, waardeur, in teenstelling met die Reformatoriese leer van die paradoksale eenheid van die inhoud van die geloof en die toeēiening daarvan deur die Heilige Gees, 'n splitsing gekom het deur die fides qua eensydig te beklemtoon teenoor die fides quae as belangrikste element van die geloofsbeskouing. As reaksie teen die valse objektivisme, het die wending tot subjek-tivisme gevolg as tendens wat beliggaming gevind het in die idealisties georiënteerde godsdiensbegrip van Schleiermacher. Beide, Bultmann en Barth, dink nie in die objek-subjek skema nie, maar nie op dieselfde wyse nie. Ons bepaal ons eerstens kortliks by Barth se beskouing. 
Reeds is vasgestel dat inhoud van die verbond God-met-ons is en dit impliseer die saamwees van God en mens in 'n gemeenskaplike geskiedenis as heilsgeskiedenis. In gedagte moet gehou word dat die kern van die Christelike boodskap nie 'n idee is nie, maar ' $n$ inklusiewe gebeurtenis, dit is 'n geskiedenis wat die totale gebeure van Godmet-ons insluit en so dan ook die verhaal van almal wat daarmee gemoeid is. Inklusiewe geskiedenis of gebeure is ' $n$ nuwe begrip wat Barth invoer en dit beteken niks anders nie as 'n omskrywing van die naam Jesus Christus. Dit beteken dat wat die Bybelse getuies sê, werklikheid is wat die lesers en hoorders daarvan ook insluit, nie kragtens 'n inherente oortuigingsmag van gebruikte begrippe nie, maar kragtens hierdie Naam self. Die hart van die kerk se boodskap is dat Jesus Christus die daadwerklike God-met-ons is en hierdie boodskap word oorgebring met die vertroue dat Christus daarvoor verantwoordelik is, dat $\mathrm{Hy}$, as die waarheid, self daardeur spreek en gehoor word en dat Hy self, omdat die verkondiging in Christus se diens geskied, werklik teenwoordig is as sy eie getuie (Barth 1963:17). Jesus Christus kan nie anders verkondig word as die Een wat Homself verkondig nie. Daarom sê Barth (1959:80), dat menslike handeling, spreek en hoor in Christus se diens, nooit anders kan geskied nie as in gebed en verwagting dat Christus dit alles altyd self weer sal doen.

Bultmann oorwin die objek-subjek teenstelling deur die objektiewe getuienis van die Skrif eers subjektief te laat verwerk. Dit gaan vir hom om 'n hermeneutiese probleem. Vir Kuitert (1966:37v) gaan dit in die hermeneutiek om verstaansleer, om die kuns om 'n vers te verstaan. Vir Bultmann, volgens Kuitert, gaan dit om die universele teorie oor verstaan self. Die vraag is hoe die historiese verlede vir ons in die hede iets sinvols kan meedeel. Voorwaarde hiervoor is wat Bultmann die saak van lewensbetrekking noem, en dit weer is iets wat met ' $n$ mens se menswees te doen het. Sover 'n teks my in my menswees raak, kan ek dit verstaan. Daar is slegs een gemeenskaplike interesse tussen outeur, hoorder en leser, en dit is aandag vir die groot vrae in verband met die verwerkliking van ons menswees. Dit is die een gemeenskaplikheid wat die verstaan van die Nuwe-Testament moontlik maak, vandaar die term: eksistensiale interpretasie. Kuitert vat dit miskien baie kort soos volg goed saam: om die Nuwe-Testament te verstaan moet gepoog word om deur die voorstellingswêreld van die Nuwe-Testament te dring tot die saak en om vas te stel watter kernervaring deur daardie wêreld te voorskyn tree, naamlik die ervaring van of ontmoeting met God in God se selfopenbaring. Die Bybel wil van hierdie ervaring spreek, maar dan volgens die grondreël: van God kan ons alleen praat as ons sê wat God aan ons doen, of watter ervaring God vir ons in ons menswees beteken. Die Nuwe-Testament moet ons dan ook lees as getuienis van die ervaring wat die getuies gehad het van die selfopenbaring van God. Hulle getuienis is eintlik hulle selfinterpretasie. Vir Barth is die Bybelse ge- 
tuienis geldig omdat die naam, Jesus Christus, meester is van daardie gebeure en almal wat dit verneem. Daarom is dit nie iets objektiefs wat eers subjektief verwerk moet word nie, maar die werklikheid wat sprekers en hoorders reeds omsluit. Anders gesê, Jesus Christus as God-met-ons, is nie 'n frase nie, maar Hy is Immanuel, die God-metons. Die verskil tussen Barth en Bultmann le dieper as die objek-subjek probleem.

Voordat enkele aspekte uit die versoeningsleer uitgelig word, moet nagegaan word waarom Barth van versoening praat as vervulde verbond en met die oog op die sonde, nie net van herstelde verbond nie. Hy beklemtoon dit dat God van alle ewigheid nie God vir Godself wou wees nie, maar nie God wou wees sonder die mens nie. Van alles wat God geskep het, is net die mens ingesluit in God se verbond, met die belofte en versekering: 'Ek wil julle God wees.' Die verbond is dus vir Barth wesenlik genadeverbond, gegrond in God se vrye en ewige verkiesing. Soos die geval met die skepping van die mens, so is God se ewige selfbeskikking ook die vooronderstelling van die mens se versoening met God. Die insluiting van die mens as deelgenoot van God in die genadeverbond, beteken die plig tot dankbaarheid aan die kant van die mens. Dit is die enigste, die noodwendige, wat aan die kant van die mens moet geskied. Om ander, valse gode te gehoorsaam, is gewoonlik 'n saak van vrye wens en oordeel van die mens. Waar God wat God-vir-ons is, die een is wat beveel, daar is gehoorsaamheid nie opsioneel nie, maar die vanselfsprekende ooreenstemming en menslike antwoord. Die verskriklikheid van die sonde van ongehoorsaamheid daarteenoor, kom juis in die bestaan van die mens in die verbond en wel as genadeverbond, eers dan aan die lig (Barth 1953:44-45). As die verbond van meet af aan as genadeverbond verstaan word, en as die gebod van God, naamlik 'julle moet my volk wees', tevore reeds deur Barth (1946:564) as vorm van die evangelie aangetoon is, dan geld tegelyk daarmee dat God se selfbeskikking - in die sin dat God Godself beweeg tot iets - altyd ook beskikking tot versoening was, en wel in Jesus Christus, omdat dit ook altyd God se selfbeskikking tot gemeenskap met die mens as God se skepping was.

Hou ons ons aan die kort samevatting van Otto Weber (1963:195), beteken dit egter verder dat die versoening wel deur die sonde veroorsaak is, maar nie daarin gefundeer is nie. Verder beteken dit dat die versoening nie ' $n$ toevallige werk van God saam met ander is nie, maar wesenlik en noodwendig in ooreenstemming met God se verbond plaasgevind het. Volgens die gesigspunte van Barth kan die sonde niks anders as 'n insident wees nie. Dit is nie magtig genoeg om God tot handeling uit te daag nie. Dit vermag nie meer as om die aanleiding te word ten opsigte waarvan God se verbondsverhouding as trou, betoon en deurgevoer word nie. Dit beteken nie dat sonde maar gering geskat kan word nie. God beskou die bedreiging daarvan vir die voortbestaan van die skepping in so ' $n$ ernstige lig, dat God self in die stryd daarteen in die 
kryt gegaan het. Dit is die versoening wat openbaar dat dit alleen vanaf die Nee van God bestaan, dat dit in al die verskriklikheid daarvan alleen aan die linkerkant van God leef en werk (Barth 1963:49). As Barth van die kwaad, die Bose (Duiwel) praat, gebruik hy die begrip Nichtige. Dit is 'n moeilike begrip wat makliker beskrywe as vertaal kan word. Dis vervorming van die woord 'nie', en die begrip 'niks'. Dit is dit wat God nie geskep het, wat God nie gewil het nie en nooit sal wil nie, en geen plek het in God se skepping nie. Die verskriklikste is dat hierdie insluiper in God se skepping, juis bestaan en werklikheid gekry het deur God se bondgenoot, die mens. Gesien in die versoeningslig, is sonde niks anders as wanorde, van God af gesien as die onbegryplike, onmoontlike, ontoelaatbare. In die versoeningswerk tree dié God in die strydperk, wat die sonde van tevore reeds kragtig ontken en opsy geskuif het. Daarom kan dit nooit as te nimmer vooronderstelling van die versoening wees nie, slegs aanleiding daartoe. Daarteenoor is die versoening alles behalwe 'n reaksionêre daad teen die uittarting van die sonde, maar die positiewe wil van God as werk van God se regterhand (Barth 1963:49). Die versoening is nie net ' $n$ insident soos die sonde nie. God het nie mens geword om die sonde uit die weg te ruim nie, maar voor alles om konkrete gestalte aan die belofte te gee: 'Ek wil julle God wees' en die gebod 'julle moet My volk wees'. Met goddelike volmag wou $\mathrm{Hy}$ en het Hy hierdie belofte en gebod vervul. Die oorwinning van die mens se sonde deur die versoeningsdsdaad moet derhalwe verstaan word as daad van bevestiging en uitvoering van God se oorspronklike oogmerk met die mens, en Jesus Christus, die versoener, is die eerste, enigste ernstige en vervulde Woord van God in die tyd. Van die kant van God is die versoening derhalwe 'n noodwendige gebeurtenis en hierdie karakter ontleen dit aan die verbond en God se blywende trou terwille van die verbond. $\mathrm{Al}$ het die mens 'n ontroue en vervreemde bondgenoot geword, het dit God se verbond met die mens nie opgehef nie. Daarom beteken versoening nie herstel van 'n verbreekte verbond nie, maar eerder herstel van die plek van die ontroue bondgenoot binne die verbond deur die regverdigende genade van die Heer van die verbond.

Omdat die verbond vooronderstelling van die versoening is, is laasgenoemde vir Barth geheel en al Christologie. Die inhoud van die versoeningsleer kan dan ook met een sin weergegee word as kennis van Jesus Christus. Dit bestaan uit 'n drievoudige kennis:

* as ware God, dit is God wat Godself verneder en dus versoenende God is;

* ook as ware mens, dit is die mens wat deur God verhoog is en dus versoende mens is;

* in die eenheid van ware God en ware mens, as borg en getuie van ons versoening. 
Hierdie drievoudige kennis van Jesus Christus sluit die kennis van 'n drievoudige gestalte van die mens se sonde in: (a) as hoogmoed, (b) as traagheid en (c) as leuen. Verder sluit die drievoudige kennis van Jesus Christus die gebeure in waardeur die versoening voltrek word:

** as regverdiging,

** as heiliging,

** as roeping van die mens, asook kennis van die werk van die Heilige Gees, in

** versameling,

** opbou en

** sending van die kerk.

Ten slotte beteken kennis van Jesus Christus ook kennis van die bestaan van die Christen in: geloof, liefde en hoop (Barth 1953:83).

\section{KERKLIKE VERKONDIGING IN PERSPEKTIEF VAN DIALEKTIESE TEOLOGIE}

\subsection{Resiproke verhouding van verkondiging en teologie}

Histories sou die ontstaan van kerklike teologie teruggevoer kon word tot die Apologete wat die evangelieboodskap van die kerk verdedig het toe dit deur die heidense filosoof Celsus bevraagteken is. Oorspronklik gaan verkondiging aan teologie dus vooraf. Van die ontstaan van die teologie af is die eintlike oogmerk van die teologie derhalwe om waghond te speel oor die suiwere verkondiging van die kerk. Hoewel nie dieselfde nie, bestaan daar tog ooreenkoms tussen wat teologies beweer en kerklik geleer word. Verskuiwings in die teologie vind gewoonlik weerklank in die prediking. Hoewel dit so is dat normaalweg vrae vanuit die teologie aan die verkondigers van die kerklike boodskap gestel word, kan dit ook gebeur dat vrae deur die verkondigers van die evangelie, aan die wagters op die teologiese Sionsmure gestel kan word, wat verskuiwings in die teologie tot gevolg kan hê.

Dit is presies die wyse waarop die dialektiese teologie gebore is. Dit het nie in die studeerkamer van 'n teologiese professor begin wat daagliks besig was met die voorbereiding van 'n akademiese lesing nie, maar wel in die studeerkamer van 'n dorpspredikant wat week na week 'n preek moes voorberei vir die Sondagse erediens(te). Hy self was 'n gepromoveerde in die teologie wat as student aan die voete van vermaarde geleerdes soos Adolf von Harnack en Wilhelm Herrmann gesit het. Die gesigte 
van honderde kerkgangers met oë Sondag na Sondag strakverwagtend op hom gerig, het die kwelvraag laat ontstaan, wat dit dan tog sou wees wat hulle graag wou hoor? Dit kan tog nie die leraar se siening oor allerlei sake van die dag wees nie, want daaroor kan die siening van professionele politici en ander geleerdes in die nuusblaaie en ander publikasies gevind word. Dit kan tog ook nie die predikant se eie godsdienstige ervarings wees of sy of haar vermoë om aangrypende morele lessies op te dis nie, want daarvoor het 'n mens nie 'n lang teologiese studie nodig nie. En al weet die kerkgangers dit miskien almal ook nie, het dit vir Barth met heilsame skrik duidelik geword dat kerkgang alleen dan sinvol word as dit daarin voor alles gaan om te hoor wat die Gees vir die gemeentes sê. En die Gees maak gebruik van die Woord en van 'n dienaar van die Woord wat erns maak met die studie van die Woord. Dit was die begin van Barth se ernstige bemoeienis met die Bybel as Woord van God. Dis eintlik vanselfsprekend dat ' $n$ verantwoordelike leraar in so 'n krisissituasie sal terugval op sy of haar teologiese reservoir. Die teologiese gedagtewêreld waarmee Barth bekend geraak het, is hoofsaaklik bepaal deur die misties gevoelsmatige godsdiensbeskouing van Schleiermacher en die Kantiaans georiënteerde etiese beskouing van Ritschl. Kortliks kom Barth se besware teen die heersende teologiese gedagtes, wat ook neerslag in die prediking gevind het, op die volgende neer (Allen 1950:9vv):

* Hy beskuldig die teologiese woordvoerders van subjektivisme. Daar is by hulle meer bekommernis oor mense se gevoelens en ervarings as oor die Goddelike waarheid soos geopenbaar in die Bybelse getuienis van Jesus Christus.

* Voorgaande gaan gepaard met 'n kapitulasie voor die geskiedenis. Die dogma van die kerk, soos vervat in kerk se belydenis, word opgebreek deurdat elke onderdeeltjie daarvan verklaar word as produk van historiese omstandighede, en wat nie histories verklaar kan word nie, kom onder verdenking. Aandag word meer gegee aan literêre, sosiale en historiese studies, terwyl die leerstellige deel van die teologie verwaarloos word.

* Barth tipeer die teologie van sy tyd as Vrysinnige Protestantisme, wat volgens hom, Christus verraai het voor die moderne gees en dié se maatstawwe.

Enkele van die hoofmotiewe in die teologie van Barth kom hier reeds duidelik na vore. Uitgaande van sy vasstelling dat God self aan die woord behoort gestel te word in die prediking (Koopmans 1949:118vv), het sy toegespitste aandag aan die betekenis 
van die uitdrukking, 'Woord van God', daartoe gelei dat hy tot die konklusie gekom het dat dit daarin nie gaan om wat ons van God, maar wat God oor ons te sê het (Noordmans 1930:41, 45). Dit gaan daarin nie om religieuse beskouings en ervarings nie, maar om openbaring, bekendmaking van God self. As dit ingesien word, verplaas die middel en uitgangspunt van ons denke, weg van die mens af na God toe en daarom van God af sub specie Dei.

Die ander besware teen die teologie van die Vrysinnige Protestantisme, het tans weer aktueel geword. Telkens kom sommige dogmas van die kerk, soos uitgedruk in die belydenis, onder skoot. So kom die opstanding van Christus as historiese gebeurtenis in die gedrang en word verklaar as noëtiese teenbeeld van die kruisiging. Die verraad van Christus voor die moderne gees en dié se maatstawwe is vandag ook 'n waarskuwing teen die swaar beklemtoning van kontekstuele teologie en prediking, wat soos reeds gemeld maklik kan lei tot 'n evangelie wat deur mense uitgedink is.

\subsection{Kontrole en korrektuur van kerklike verkondiging vandag}

Die dialektiese teologie, en in die besonder die teologie van Barth, beteken soos reeds gemeld, nie net terugkeer en weereens erns maak met die grondbeginsels van die Reformatoriese teologie nie, maar ook verdere selfstandige teologiese denke in Reformatoriese lyn. Kontrole en korrektuur van kerklike verkondiging in dialektiesteologiese perspektief, beteken dan voor alles toetsing van die verkondiging aan die Reformatoriese grondbeginsels, plus die nuwe wat in sekere gevalle daarby gevoeg is, ooreenkomstig die siening van die dialektiese teologie. Hierdie grondbeginsels kan op hulle beste met enkele bekende, tradisionele Reformatoriese woorde en begrippe aangedui word as: sola Scriptura, sola gratia, en sola fide. Hierdie drie fundamentele beginsels wat die kern van die Reformasie uitmaak, is gegrond in en word gedra deur die diepste grond van Reformatoriese denke, naamlik die solus Christus, waarskynlik dié kenmerk van Barth se teologie. Getrou aan die Reformatoriese denke, begin hy sy versoeningsleer, deur in sy reeds gekwoteerde inleidingsstelling te beklemtoon dat God in die versoeningsdaad die verlore saak van die mens God se eie gemaak het in Jesus Christus. Omdat die versoening in Jesus Christus die kern van die boodskap is wat die kerk ontvang het en moet verkondig in die wêreld en omdat versoening vervulling van God se genadeverbond is en die kennis van versoening in die kennis van Jesus Christus geleë is, kan die kontoere van kerklike verkondiging in perspektief van dialektiese teologie dus soos volg aangedui word:

\subsubsection{Kerklike verkondiging is Christus-verkonding}

Kerklike verkondiging, in opdrag van God, is die oordra van die goeie nuus aan al die mense in die wêreld en dit handel oor Jesus Christus in Wie God wat van ewigheid af 
nie God sonder die mens wou wees nie, self mens geword het, in die plek en ter wille van die mens Godself laat beskuldig, veroordeel en tereggestel het en Godself met die wêreld, en die wêreld met God versoen het en in Wie God die versoende mens verhoog het tot die heerlikheid by God. Kerklike verkondiging wat nie na elke prediking, elkeen wat dit aangehoor het, terug uit die huis van God, die lewe en die wêreld as bevryde laat ingaan met 'n loflied van blye dankbaarheid en diepgevoelde berou oor sonde wat deur ' $n$ Ander gedra en weggedra is nie, was nie evangelieverkondiging nie.

Kerklike verkondiging is Christus-verkondiging en dit weer is verkondiging van God se trou aan die genadeverbond wat God ondanks die ontrou van die mens as die bondgenoot, in die versoeningswerk in Jesus Christus tot vervulling bring. As in gedagte gehou word dat die bediening van die versoening aan die kerk toevertrou is as verkondigingstaak - is dit 'n saak van die aller uiterste belang, dat met brandende ems aandag gegee word aan die waarskuwing van Barth, dat verkeerde of gebrekkige kennis van die versoeningsleer, noodwendig verskraling of verduistering van die boodskap van die kerk beteken. Dit is tragies, maar waar, dat die blokkasie in die hartaar van die kerk, die Christus-verkondiging as evangelie van God, dikwels die corsaak is dat die liggaam van Christus nie meer Skriftuurlik funksioneer nie, maar met allerlei natuurlike lokmiddels kunsmatig aan die lewe gehou moet word.

\subsubsection{Sola Gratia}

Die Reformatoriese klem op die sola gratia is ' $\mathrm{n}$ afwysing van die werkgeregtigheid as menslike bydrae tot die Goddelike vryspraak van sonde. Sonder gevaar van teenspraak sou beweer kan word dat die betekenis van die woord en begrip 'genade' in teologie en verkondiging nooit ontken is nie, ook wat die versoeningsleer betref. Dit neem nie weg nie dat 'katoliserende' invloede kon ingesypel het in Protestantse kerkwees. Rooms-Katolieke teologiese denke onderbeklemtoon eenheid van God se genade deur dit op te breek in dubbele reekse soos byvoorbeeld gratia increata en gratia creata. Die geskape genade word dan teenoor die ongeskape genade van God gestel en wesenlik verskillend daarvan. Barth breek heeltemal met die beskouing van Rome oor die eenheid van God se genade in Jesus Christus. Hy is van oordeel dat die gesplete genadebeskouing die getuienis van die Skrif in gedrang bring, want daar is net een God en een Middellaar tussen God en ons, gevolglik kan daar net een genade wees as ons nie in sinnelose abstraksies wil verval nie (Barth 1953:92). Dit moet vir Protestantse kerke ook rede tot ernstige nadenke wees dat Rooms-Katolieke kringe, wat die gratia infusa opvatting toegedaan is, die wêreldwye charismatiese beweging met soveel entoesiasme verwelkom het. 


\subsubsection{Die eksklusiwiteit van Jesus Christus}

Vir Barth is genade nie 'n grootheid naas of los van God nie, maar 'n volkomenheid van God. Dit beteken dat God Self genade is, soos God ook liefde is. Eintlik is God se genade God se liefde in aksie: God het die wêreld so lief gehad dat God se enigste Seun gestuur is. Vir Barth is God se genade die daad van grensoorskreiding na die mens toe, en watter mens was en is dit nog altyd nie! Genade het altyd die konnotasie van laer afkom, afdaling, vernedering. Dit was vir God nie te veel om in God se ewige Seun af te daal tot die bodemlose diepte van verlorenheid en om daar in Jesus Christus as broer langs die mens te gaan staan, in die mens se plek beskuldigde, veroordeelde tereggestelde te word nie. Daarom het God Christus uit die dood opgewek tot nuwe lewe, die nuwe lewe wat Christus namens die ou mens van sonde wat doodgemaak is, in ontvangs geneem het en bewaar vir die dag van sy laaste koms in koninklike heerlikheid. God se grensoorskreiding beteken egter nie dat God afstand doen van Goddelike heerskappy nie. Wat God doen, is 'n soewereine handeling wat God aan niemand verskuldig is nie. Hierdie genadedaad is nie 'n uitsondering op 'n algemene reël nie, maar God se eie beskikking op grond van die genadeverbond van alle ewigheid. Die ware fundering van die eksklusiewe Paulinies-Reformatoriese 'deur die geloof alleen', is in die eie woorde van Barth (1953:706; my vertaling):

die eksklusiwiteit van Hom in wie die geloof glo. Die sola fide is die swakke maar noodwendige weerklank van die solus Christus. In Hom alleen word die sondaar geregverdig en as sodanig bekend. Hy alleen het boete gedoen waardeur die omkeer van die mens na God toe werklikheid geword het. Hy alleen het die wêreld geoordeel deurdat Hy Homself deur die wêreld vir die wêreld laat teregstel het. Hy alleen het daarmee bewys dat Hy die Een is wat die oue beëindig en die nuwe laat ontstaan het. Omdat geloof alleen in Hom geloof kan wees, daarom is dit net in daardie eksklusiewe eensaamheid regverdigende geloof. Daarom verag en verwerp dit alle medewerking en konkurensie deur een of ander poging van 'n mens om jou omkeer na God toe self te bewerk en te voltrek, om self die aand van die verlede en die môre van die. toekoms in werk te stel.

As 'n mens in Jesus Christus glo, erken en gryp jy sy geregtigheid vas as vreemde geregtigheid van hierdie Een wat in jou plek die geregverdigde mens is.

Die klem wat Barth lê op die eksklusiwiteit van die geloof, gegrond in die eksklusiwiteit van Jesus Christus, het hom die kritiek van 'genademonisme' op die hals ge- 
haal, met die verwyt dat die mens as 'n niks totaal uitgesluit word. Die teendeel is eerder waar, en vir die verkondiging van die gesonde leer is dit belangrik om na sy eie woorde te luister. Hy sê die beskuldiging is nie net 'n ontsettende vereenvoudiging nie, maar totale onsin. Sonder God se genade sou die mens as verbondverbreker inderdaad in ewige niks verlore wees. Deur die prysgawe van Jesus Christus as God se Seun in Wie God die wêreld met Godself versoen het, is God inderdaad alles, sodat die mens nie niks nie, maar juis God se mens en binne die grense van mensewees alles mag wees. Die betekenis van die versoening in Jesus Christus is dat die mens teenoor God nie as subjek wegval nie, maar eerder as nuwe subjek van Bo af geskep en gevestig word. Die mens is in die versoening deur Jesus Christus as nuwe subjek in verhouding tot God 'n werklikheid. Die mens word deur die 'genade alleen' dus nie geabsorbeer nie, maar in ooreenstemming met die Reformatoriese visie, bevry tot die nuwe bestaan in Jesus Christus: God het ons dan nou vrygespreek omdat ons glo. Daarom is daar dus nou vrede tussen ons en God (Rom 5:1).

\subsubsection{Die 'nuwe' mens}

Die nuwe bestaan van die mens in Jesus Christus kan eers reg verstaan word as ons let op Barth se beskrywing daarvan. Christelike bestaan word aangedui as so een wat hierdie nuwe bestaan weerspieël en wel in sover as wat dit, as menslike handeling gegrond in die werk van die Heilige Gees, ooreenstem met wat God in Jesus Christus tot stand gebring het. Die nuwe bestaan van die versoende mens is geleë in sy omkeer na God toe in Jesus Christus en dit bevat drie verskillende aspekte wat met die begrippe: geloof, liefde en hoop, aangedui kan word. Vir die Christen is hulle net in Christus, as verborge, ook bekend; as bedekte net in Hom openbaar en as bewaardes in Hom, ook meegedeel (Barth 1953:99). Hierdie omkeer van 'n mens na God toe, vind plaas deur 'n Goddelike oordeelsuitspraak oor jou wat uit 'n afwysende en toewysende aspek bestaan. Hierdie Goddelike regspraak is nie net uitgespreek nie, maar ook voltrek: die mens, die oortreder, die sondaar en verbondbreker, bestaan nie meer nie. Met die mens word nie meer rekening gehou nie en die mens het geen toekoms nie. In die mens se plek as kwaaddoener het Jesus Christus getree en die dood wat die kwaaddoener toekom, het Hy gesterf. As verbondbreker het die mens verdwyn toe die mens met en in die Man wat aan die kruis gesterf het, in die graf weggele is (Barth 1953: 100 ).

Hierdie gebeurtenis is die Goddelike oordeel en die woord waaraan die Christelike geloof glo. God se oordeel het egter ook 'n positiewe, toewysende, 'n geregtelike toegekende kant, naamlik dat God die mens aanneem en mense hullewelf mag ken as getroue diensknegte, as vriende en God se liewe kinders. In eie bestaan sal mense hulleself egter nooit só kan ken nie. In eie bestaan sal mense hulle nooit en nêrens as ge- 
regverdigdes kan sien nie, maar steeds as diegene wat behoefte aan regverdiging het. Die geloof waaraan die geloof vashou, sluit geloof aan sigself derhalwe uit. As ou mens het die mens immers in Christus gesterf en alleen in Christus is die mens as nuwe mens geskep (1953:105). Dit is dit wat ook, heeltemal in ooreenstemming met Reformatoriese teologie, onder 'regverdiging deur die geloof alleen' verstaan word (Barth 1953:104).

\subsubsection{Heiliging}

Die versoeningsdaad van God in Jesus Christus, ware God en ware mens, bestaan volgens Barth nie net in die vernedering van God nie, maar tegelyk - en dit is die nuwe in sy versoeningsleer - daarmee, in die verhoging van die mens; nie net in die regverdiging van die mens nie, maar tegelyk daarmee in die mens se heiliging; nie net in die geloof sonder werke nie, maar in die liefde met werke. Die probleem waarmee ons hier te doen het, staan in verband met die omkeer van die mens na God toe, tot wie God Godself gewend het in Jesus Christus. 'Ek wil julle God wees': dit is die regverdiging van die mens. 'Julle moet my volk wees': dit is God se heiliging. 'n Verkeerde begrip van wat heiliging werklik is en wat die verhouding daarvan tot regverdiging is, kan wat die prediking betref, die verskil wees tussen 'n angswekkende moralistiese donderstorm met harde slae alleen, en verkondiging van die evangelie in die gestalte van wet en verordening as 'n sagte verkwikkende reën.

Vir Barth beteken die feit dat die mens onder God se gebod, God se geweldige opdrag, geplaas is, tegelyk dat die mens reeds verplaas is in die gebied van vrede met God, oorgeplaas in die vryheid van God se kinders. Jesus Christus het deur opstanding en verhoging die lewe van die nuwe mens tevoorskyn laat tree en weer vir alle mense ruimte geskep tot ' $n$ bestaan van vrede met God. Jesus Christus is God se magtige bevel om hierdie gebied te betrek en in hierdie ryk te lewe. Meer as dit nog, is Hy God se magtige bevel om ons oë te open en oop te hou en bewus daarvan te word dat dit die gebied is waarin ons hoort, waarin ons reeds is, bestaan en moet bly. Woorde soos bevel, gebod, ordening ensovoorts kan maklik die misverstand laat ontstaan dat die mens self nog sekere beslissings en dade moet verrig. Die Goddelike eis van God se bevel is egter gegrond in die feit dat die mens in Jesus Christus reeds verplaas is in die ryk en ruimte van vrede met God. Gehoorsaamheid aan hierdie bevel kan slegs beteken om daarin te begin lewe en asem te haal. Hierdie bevel het 'n mens nodig, want uit jouself en deur wat jy doen, het jy nie toegang tot hierdie vryheid nie. Die vryheidsryk is nie 'n ryk waarin jy jou as baas kan gedra nie. Jy moenie dink dat jy na eie goedvinding hier kan optree nie. Doen jy dit, beteken dit dat jy reeds hierdie ruimte verlaat het (Barth 1953:107vv). 


\subsubsection{Regverdiging}

Dit blyk dus dat God nie net handelende subjek in die versoening is nie, maar ook in die omkeer van die mens na God toe. God is die regverdigende en die heiligende. Dit is vir die Skriftuurlike verkondiging van die kerk baie belangrik om helderheid te verkry oor die verhouding van regverdiging en heiliging. Eerstens moet opgemerk word dat dit een, enige, unieke daad van God in Jesus Christus is. Dit geskied nie in temporele volgorde nie. Beide word tegelyk tot uitvoer gebring, in en met die een ook die ander. Hoewel nie geskei nie, is dit tog twee onderskeie momente in die een gebeurtenis en is dit ook twee onderskeie aspekte wat nie met een woord beskryf kan word nie, maar net as regverdiging en heiliging. Dit alles is in ooreenstemming met die een historiese bestaan van Jesus Christus as ware God en ware mens. Dat Jesus Christus ware God en ware mens in een persoon is, beteken nie dat sy Godheid en mensheid een en dieselfde is nie en die een dus in die ander verander is nie. Reeds van die Chalcedon belydenis kan afgelei word dat ook regverdiging en heiliging as twee momente van die een versoeningsdaad wat in Jesus Christus plaasgevind het, nie identies met mekaar is nie en as begrippe nie verwisselbaar is nie. Dit blyk ook uit die besondere inhoud van hierdie twee begrippe: hulle is 'onvermengd en onverwisselbaar'.

Regverdiging is nie heiliging nie en gaan nie daarin op nie, en die omgekeerde is net so waar. So seker as wat beide onlosmaaklik saam hoort, net so min kan die een deur die ander verklaar word. Die menslike antwoord as geloof, op die Goddelike daad waardeur die sondige mens die geregtigheid mag aangryp wat in Jesus Christus belowe word, is een saak. Die gehoorsaamheid, die liefde as in ooreenstemming met die heiligheid wat vir die mens in Jesus Christus meegedeel is, is egter 'n ander saak. As nie ag geslaan word op die 'onvermengd en onverwisselbaar' nie, kan die verlossingsleer daarin mank gaan dat die regverdiging heeltemal opgaan in die mens se heiliging, wat alternatiewelik beteken dat die geloof in Jesus Christus wat as regter in ons plek tereggestel is, in gehoorsaamheid verdwyn, waardeur die Christen in navolging van Hom, vir die wêreld en die mens moet sterwe. Hierdie laaste reken Barth kan as die grootste bedenking teen die teologie van Bultmann aangevoer word. Maar die heiliging kan ook heeltemal opgaan in regverdiging, miskien op grond van die inderdaad geweldige indruk van die troos van die genade wat in die regverdiging werksaam is en verstaan moet word.

Ten slotte moet die aandag nog gevestig word op die feit dat regverdiging en heiliging onderling onskeibaar saam hoort, omdat hulle net twee momente en aspekte is van een en dieselfde handeling van die een Goddelike subjek. Verwaarlosing van wedersydse betrokkenheid moet noodwendig lei tot valse stellings en praktiese vergissings. Verwaarlosing van betrokkenheid van regverdiging op heiliging, lei tot die voor- 
stelling van 'n eensaam handelende God en Sy 'goedkoop genade', en derhalwe tot 'n trae non-aktivisme. Waar die betrekking van heiliging tot regverdiging vergeet word, lei dit tot die voorstelling van 'n eensaam handelende mens wat sigself begenadig en derhalwe tot illusionistiese aktivisme (vir die hele probleem 'regverdiging en heiliging', vgl Barth 1955:565vv).

\subsubsection{Jesus Christus as God se belofte}

Soos die geloof antwoord is op God se regverdigende vryspraak, die liefde antwoord op God se gebod is, so is hoop die antwoord op die mens se bevestiging en toerusting tot draer van God se belofte. Ook wat dit betref, het Barth 'n nuwe geluid laat hoor. Teenoor die Reformatoriese en tradisionele teologie van daardie tradisie, wat in die prediking hoofsaaklik die klem op regverdiging en heiliging, geloof en liefde laat val en dikwels hoop slegs as ekwivalent van geloof laat geld, beskou Barth belofte en hoop as element wat selfstandig corweeg moet word en vanselfsprekend in die prediking meer aandag behoort te geniet.

Die deur en deur eskatologies gerigte boodskap van die Nuwe-Testament behoort die teologie aan te spoor om die Reformatoriese eensydigheid op hierdie gebied te oorkom. Volgens Barth is die herstel, vernuwing en vervulling van die verbond op sigself weliswaar volkome. Dis egter nie 'n einde nie, maar 'n begin. Doel van die versoening volgens Johannes 3:16 is die ewige lewe, en omdat alleen God ewig lewe, beteken dit lewe saam met God. Daarmee word, soos so dikwels gereken word, nie 'n statiese rus in God, salige betragting en aanbidding alleen bedoel nie, maar in ooreenkoms met Lukas 20:36, 'n bestaan van die mens in dienende samewerking met God en derhalwe 'n bestaan in eie vrye mede-verantwoordelikheid van die mens vir die saak van God (Barth 1953:121, 123; Weber 1963:199). Soos God se regverdiging en heiliging van die sondaar alleen in Jesus Christus werklik is, so is Hy ook God se belofte. Daarom is die toekoms wat ons verwag, onlosmaaklik met Chrestus se finale koms verbind. Hy is die vervulling van God se toekomsbelofte. Hy is die mens wat ewig lewe en as sodanig die toekoms van die wêreld en elke mens en die hoop van die Christen (1953:127).

\subsubsection{Skrifbeskouing}

Ten slotte moet die aandag gevestig word op Barth se Christosentriese beskouing, ok van die kardinale Reformatoriese sola Scriptura. Hy waarsku teen 'n gedesentraliseerde Skrifbeskouing en bedoel daarmee dat 'n bepaalde deel van die Bybelse boodskap los van die sentrum van die Skrif, Jesus Christus, mensgeworde Woord van God, op sigself as geopenbaarde waarheid verstaan word. Die gevaar is dat die Bybel dan 
langs ander boeke gelê en soos ander boeke gelees kan word. Op die duur sal die vraag nie ontwyk kan word nie of 'n mens die boodskap van die Bybel nie ook aanvullend uit ander boeke kan verneem nie. Dit impliseer 'n tweede norm vir kerk en teologie naas die Woord van God waartoe 'n mens toegang kan kry deur jou verstand. Prakties beteken dit dat dit nie uitgesluit kan wees dat die teks vir die prediking uit die Bybel geneem word, maar die inhoud van die prediking uit allerlei ander boeke kom. Mag die enkele grepe uit die dinkwêreld van Barth, almal wat geroep is tot die bediening van die versoening, nie net op die hoede stel teen hierdie groot gevaar nie, maar ook as prikkel dien tot ernstige nadenke oor die kwaliteit van hulle verkondiging in hierdie tyd.

\section{Literatuurverwysings}

Allen, E L 1950. The sovereignty of God and the word of God: A guide to the thought of Karl Barth. Nederlandse vertaling deur M E Groneman. Assen: Born N.V. Barth, Karl 1947. Dogmatik im Grundrisz. Zollikon-Zürich: Evangelischer Verlag.

— 1948. Die kirchliche Dogmatik, Vol 111/2. Zollikon-Züich: Evangelischer Verlag.

1953. Die kirchliche Dogmatik, Vol IV/1. Zollikon-Zürich: Evangelischer Verlag.

— 1955. Die kirchliche Dogmatik, Vol IV/2. Zollikon-Zürich:Evangelischer Verlag.

- 1957. Die kirchliche Dogmatik, Vol IV/3 (1). Zollikon-Zürich:Evangelischer Verlag.

1959. Den gefangenen Befreiung. Zollikon-Zürich:Evangelischer verlag.

Brunner, Emil 1929. Die Andere Aufgabe der Theologie. Zwischen den Zeiten, 25527.

1931. Religionsphilosophie evangelischer Theologie. München.

Haitjema, Th L 1948. Dogmatik als Apologie. Haarlem: De Erven F Bohn.

Kuitert, H M 1966. De realiteit van het geloof. Kampen: J H Kok N V.

Noordmans, O 1930. Geestelijke perspektieven. Amsterdam: H J Paris.

Van Aarde, A G 1995a. Kerk en teologie op pad na die derde millennium: 'n Paradigmatiese verskuiwing van middelmatige aard. HTS 51, 13-38.

1995b. Kerk en teologie op pad na die derde millennium: Die kontekstualisering van die dialektiese teologie in 'n plurale samelewing. HTS 51, 38-59.

Van Niftrik, G C 1940. Kleine dogmatiek. s-Gravenhage: N.V.Drukkery.

1948. Een beroerder Israels. Nykerk: GF Callenbach.

1961. Kroniek. Kerk en Theologie 12/3, 181. 
Van Niftrik, G C 1969. Kroniek. Kerk en Theologie 20/3, 311.

Weber, Otto 1963. Karl Barths Kirchliche Dogmatik: Ein einfuhrende Bericht zu den Bänden $1 / 1$ bis $1 V / 3$ (2). Göttingen: Neukirchener Verlag. 